Dear Author,

Please, note that changes made to the HTML content will be added to the article before publication, but are not reflected in this PDF.

Note also that this file should not be used for submitting corrections. 


\title{
Effects of set-aside management on soil macrodecomposers in
} Hungary

\author{
3 Q1 Z. Tóth ${ }^{\mathrm{a}, *}$, E. Hornung ${ }^{\mathrm{a}}$, A. Báldi ${ }^{\mathrm{b}}$, A. Kovács-Hostyánszki ${ }^{\mathrm{b}}$ \\ a Department of Ecology, Institute for Biology, Faculty of Veterinary Science, Szent István University Rottenbiller u. 50, H-1077 Budapest, Hungary \\ ${ }^{\mathrm{b}}$ Lendület Ecosystem Services Research Group, Centre for Ecological Research, HAS Alkotmány u. 2-4, H-2163 Vácrátót, Hungary
}

\section{A R T I C L E I N F O}

\section{Article history:}

Received 26 June 2015

Received in revised form 28 October 2015

Accepted 5 November 2015

Available online $\mathrm{xxx}$

\section{Keywords:}

Agri-environmental schemes

Agrobiodiversity

Detritivores

Isopods

Millipedes

\begin{abstract}
A B S T R A C T
Increased agricultural production demands have decreased the area of set-aside fields in the European Union during the last decade. In contrast, set-aside still remains a management practice in Hungary, where the establishment of sown set-aside fields is a requirement of certain agri-environmental schemes in high nature value areas (HNVA). We tested the effects of set-aside management on the communities of macrodecomposer arthropods: isopods (Isopoda: Oniscidea) and millipedes (Diplopoda). We assessed the effects of habitat type, plant species richness and vegetation cover on species richness and abundance of these taxa. Pairs of wheat and set-aside fields of different ages (1, 2, 3 years) and additional seminatural grasslands were sampled using pitfall traps. Isopods showed a significantly higher species richness and abundance in set-aside fields compared to wheat fields. Older set-aside fields had a more positive influence on the diversity and abundance of the studied macrodecomposers than one-year-old fields. Three-year-old set-aside fields had significantly higher species richness of millipedes compared to grasslands. Plant diversity had a significant positive effect on almost all species while vegetation cover showed significant influence in the case of Brachyiulus bagnalli,Iulus terrestris and Leptoiulus cibdellus. Habitat type and plant species richness significantly affected the composition of macrodecomposer communities. Our results highlight the importance of set-aside fields as habitats for soil arthropods, particularly after an initial establishment period of two years. Set-aside fields that are out of a crop rotation for more than 2 years could be a valuable option for establishing ecological focus areas under the Common Agricultural Policy (CAP) 2013 reform in the EU, as these fields may simultaneously conserve elements of above- and belowground diversity.
\end{abstract}

(C) 2015 Published by Elsevier B.V.

\section{Introduction}

Above- and belowground biodiversity decreases due to land cover changes and disturbances, which also threatens ecosystem services supporting human well-being (Cardinale et al., 2012). Agricultural ecosystems are particularly vulnerable to environmental changes due to intensive management practices affecting soil conditions, vegetation structure and the soil invertebrate fauna (Altieri, 1999). Understanding such changes is important because half of all plant and animal species in Europe depend on agricultural habitats (Stoate et al., 2009). These agroecosystems and agricultural landscapes provide important soil related ecosystem services, i.e. the maintenance of soil fertility and structural properties, filtering and providing a reservoir for water, nutrient cycling and climate regulation (Dominati et al., 2010).

\footnotetext{
* Corresponding author.

E-mail address: zsolt.toth87@gmail.com (Z. Tóth).
}

Production and maintenance of healthy soils in agricultural areas are therefore key in the development of sustainable agriculture.

The importance of soil communities (microbiota, meso- and macrofauna) which contribute to a very diverse range of biochemical and biophysical processes has long been recognised (Barrios, 2007). But the decomposer subsystem and soil related ecosystem services are poorly understood. Several studies have demonstrated the importance of soil macrofauna in the maintenance of soil fertility (Brussaard et al., 2007; Stork and Eggleton,1992). Macrodecomposer soil arthropods, such as millipedes (Diplopoda) and terrestrial isopods (Isopoda: Oniscidea) have essential roles in litter decomposition, nutrient mineralization and the improvement of soil properties (Culliney, 2013). In addition to earthworms these organisms are responsible for the first step of the decomposition processes by fragmentation and inoculation of dead plant material (Hassall et al., 1987). Millipedes and isopods promote breakdown through their feeding and burrowing activities which supports microbial decomposition (Lavelle and Spain, 2001; Slade and Riutta, 2012). Of the 103 species of millipedes (Korsós, 2015) and 57 species 
39 of terrestrial isopods (Hornung et al., 2008) presently known from 40 Hungary, all species are detritus feeders so their function in nutrient 41 turnover can be considerable. Given their importance in nutrient 42 cycling, the lack of knowledge on how agricultural practices affect 43 these taxa is striking. The soil biological activity that can be measured 44 e.g. by litter decomposition rate, depends largely on the diversity of 45 soil organisms (Hättenschwiler et al., 2005) and is the result of 46 complex interactions (Stork and Eggleton, 1992; Scheu, 2002; Yang 47 et al., 2012). The diversity of organisms involved in the decomposi48 tion of organic matter and nutrient cycling is reduced by agricultural 49 intensification (Giller et al., 1997; Altieri, 1999; Tsiafouli et al., 2015).

Local land-use (Paoletti and Hassall, 1999; Souty-Grosset et al., 2005), microclimate (soil humidity, temperature), pH (Warburg et al., 1984; Hopkin and Read, 1992; Zimmer et al., 2001), landscape diversity and habitat structure (Dauber et al., 2005; Vanbergen et al., 2007) influence the species richness and abundance of soil decomposers. Plant species richness and plant community structure greatly affects above ground microclimate which has indirect effects on the soil fauna and on the decomposition dynamics of substrates through their chemistry, physiology, rhizodeposition and the quantity, quality (Dudgeon et al., 1990; Hättenschwiler and Bretscher, 2001; Smith and Bradford, 2003; Tripathi et al., 2013) and diversity of litter (Hättenschwiler et al., 2005; Laossi et al., 2008).

The establishment of semi-natural habitats (grassy strips, sown or naturally regenerated set-aside fields, hedgerows, treelines etc.) in agricultural landscapes is a common practice to enrich habitat diversity or to connect isolated habitats (Critchley et al., 2004; Smith et al., 2008, 2009; Kuussaari et al., 2011; Kovács-Hostyánszki and Báldi, 2012; Toivonen et al., 2013). These green patches in arable landscapes support high biodiversity and provide suitable environmental conditions for several plant and animal species (Pollard, 1968; Altieri, 1994, 1999; Sileshi et al., 2008; KovácsHostyánszki et al., 2011).

The first set-aside scheme was introduced by the EU in 1988 to reduce production surplus and since 1993 farmers have been obliged to establish at least $10 \%$ of their farmland as set-aside fields (Sotherton, 1998). However, despite the positive environmental effects, set-aside management was abolished in most EU countries in 2006 because of increasing production demands (Rowe et al., 2009). In Hungary, however, set-aside management was introduced per se as an agri-environment management scheme in certain areas under special protection, in the so called high nature value areas (HNVA) due to the occurrence of protected bird species (Ángyán et al., 2003). Rotational set-aside management has been present as part of the national agri-environment scheme since 2002 (Ángyán et al., 2003). The maximum period of setting aside a given arable field is three years. Set-aside fields are generally sown with a seed mixture of grass and leguminous species. The presence of set-aside fields contributes to a productive and ecologically balanced soil environment through improving the soil properties necessary for plant health (activation of soil biology, addition of organic matter, $\mathrm{N}$ fixation, microclimate modification etc.). Moreover these habitats may have important impacts on the adjacent cropping systems through spillover (Paoletti, 1995; Paoletti et al., 1997; Marshall and Moonen, 2002; Blitzer et al., 2012). In addition to the effects of set-aside fields on soil life, another important question is the optimal duration of the set-aside management. Various studies have investigated the age effect of set-aside fields on soil organisms (Wissuwa et al., 2012, 2013). Species richness and the abundance of plants and insects have been shown generally to increase with age of set-aside (Corbet, 1995; Kovács-Hostyánszki et al., 2011). However, this is not completely supported by the results of other studies: species richness of plants, butterflies and bees was highest on 2 year-old set-aside fields (Gathmann et al., 1994; Steffan-Dewenter and Tscharntke, 1997, 2001).

The present study aimed to test the following four hypotheses:

(i) The species richness and abundance of isopods and millipedes is higher in set-aside than in wheat fields.

(ii) Richness and/or abundance of isopods and millipedes increases in set-aside field during their 3 year duration.

(iii) Wheat fields, adjacent to older (2-3 years old) set-aside areas have higher diversity and/or abundance of millipedes and isopods than those adjacent to one-year-old fields.

(iv) Plant species richness, vegetation cover and habitat type have an effect on the abundance of individual isopod and millipede species and the composition of macrodecomposer communities.

\section{Materials and methods}

\subsection{Study site}

The study was conducted in the region of North-eastern Hungary (Heves County) in 2008 (see map in Supplementary material). $72 \%$ of the land was under agricultural management (ca. $60 \%$ arable and $12 \%$ grasslands) (Bükk National Park, 2015). The study area can be characterised as a continental climate with extreme high temperature and low precipitation in summer. The study sites belong to the Heves High Nature Value Area, which was established in the framework of the zonal action schemes of the National Agri-Environmental Programme in 2002 and covers around 40000 hectares (Ángyán et al., 2003). The grasslands were extensively mown or grazed, mainly by cattle and sheep, and no chemicals were applied. The most dominant species were Kentucky bluegrass (Poa pratensis), Pseudovina (Festuca pseudovina), and meadow foxtail (Alopecurus pratensis). The Heves HNVA was designed for the protection of rare farmland birds, especially the great bustard (Otis tarda). Establishment of set-aside fields was part of the arable farming action plan. The main crops were cereals, sunflower and oilseed rape. Farmers' fields have to be managed by regular crop rotation during the 5 year long contract period: cereal $20-25 \%$, alfalfa $20-30 \%$, oilseed rape and other crops (pea, sunflower, corn etc.) $25-30 \%$, set-aside $20-25 \%$. Fields can be taken out of production for 1-3 years. The set-aside fields were sown with a three component seed mixture comprised of two parts grass (e.g. Festuca pratensis, Festuca arundinacea, P. pratensis, Dactilys glomerata) and one part leguminous species (usually Medicago sativa) after the last harvest, in the autumn. Vegetation was mown once a year, after the 15th of June, leaving the cut vegetation on site.

\subsection{Study design}

Within the study area, one, two and three year old set-aside fields (Sa1, Sa2, Sa3) were chosen, each with an adjacent winter wheat field (W) and each pair with five (1- and 3-year-old) or six (2-year-old) replicates. Six semi-natural grasslands $(G)$ were also assigned as a control for comparison. All cereal fields involved in the study were managed similarly, fertilised with about $90 \mathrm{~kg}$ nitrogen/ha/year, and sown with winter wheat (Triticum aestivum). Grasslands were managed extensively, without fertiliser application and grazed or mown once per year. The mean area $( \pm$ SE) of the study sites was $21.37 \pm 1.78$ ha. The paired set-aside and wheat fields were similar in size and relief (difference in the field area within pairs: mean \pm SE $7.15 \pm 1.79 \mathrm{ha}$ ). 


\subsection{Sampling methods}

Macrodecomposers were sampled by pitfall traps during their main activity period, totalling three periods of two weeks from the beginning of May until mid-June, in 2008. Five traps per site were placed at a distance of $20 \mathrm{~m}$ from each other and $50 \mathrm{~m}$ from the field edge. We applied funnel traps filled with ethylene glycol. They were sunk directly into the soil and covered with plastic roofs (Obrist and Duelli, 1996). Pitfall traps were returned to the laboratory and after sorting for subsequent species identification the samples were preserved in 70\% ethanol. Millipedes and isopods were identified to species level. For identification of millipedes the keys of Blower (1985) and Korsós (2015) while for isopods the key of Gruner (1966) were used.

Pitfall trapping is a common and effective method for sampling epigeic soil fauna but it is not free of problems related to methodological bias. It is important to note that this method can be affected by structural habitat components like vegetation cover (Melbourne, 1999) and is selective for size/age and dispersion ability of surface dwelling invertebrates (Hassall, 1966). For simplicity we use the term abundance to refer to the relative frequency of trapped individuals that is an index of abundance. Our data reflect the surface activity of the species, thus abundance can be interpreted as density of active individuals. Effects of timing, weather and trapping method were the same across all samples. Thus our data can be used to test differences among treatments because species occurence and the number of trapped individuals are comparable and not affected by temporal and spatial biases.

\subsection{Vegetation surveys}

Vegetation composition was assessed at all study sites in the spring of 2008 . Ten $2 \times 2 \mathrm{~m}$ quadrates were recorded at each study site, located at various distances $(10-50 \mathrm{~m})$ from each other depending on the field size. All quadrates were at least $20 \mathrm{~m}$ away from the field edge. Species richness, cover of herbaceous plants and percentage of bare ground were visually assessed in each quadrate. For a description of the vegetation surveys see KovácsHostyánszki et al. (2011).

\subsection{Statistical analyses}

Species richness and abundance of millipedes and isopods failed to meet normal distribution assumptions for parametric tests, thus non-parametric Wilcoxon-signed rank tests were used to compare those within field pairs. That was applied to reveal the relationship/interconnection between the spatially closest field pairs, that is between an individual set-aside and its neighbouring wheat field.

Because structurally very different habitats were sampled using pitfall traps, we carried out individual-based rarefaction to reduce possible methodological bias. The rarefaction curves were combined together for both macrodecomposer groups due to relatively low total species numbers.

Effectiveness of set-aside management was measured as the difference of the dependent variables (species richness and abundance of isopods and millipedes) between the wheat and the adjacent set-aside fields. To evaluate that and to detect the effect of set-aside age on paired wheat fields we used Kruskal-Wallis rank sum tests with Dunn's post-hoc tests at 5\% Type-I error rate.

Kruskal-Wallis rank sum test with Dunn's post hoc test was also applied to compare species richness and abundance of isopods and millipedes in different aged set-aside fields and grasslands.

We applied generalised linear mixed models (GLMMs) with multivariate approach to measure the effects of plant species richness, vegetation cover and habitat type (fixed factor with five levels: winter wheat field, semi-natural grassland, one-, two- and three-year-old set-aside field) on the abundance of the individual isopod and millipede species. Since there was significant intercorrelation between plant species richness, vegetation cover and habitat type, their effects were tested in two separate models. Our data showed a negative binomial distribution thus we used the 'manyglm' method (family = negative binomial). The lack of spatial independence of the paired set-aside and wheat fields was treated by application of a random factor (location).

Since the number of collected species was relatively low (8 in total), the Wilcoxon-signed rank tests and Kruskal-Wallis tests were applied at species level, too. However species with low relative abundance (Trachelipus nodulosus: $0.51 \%$, Brachydesmus superus: $0.13 \%$ ) were excluded from these and from the redundancy analyses.

The influence of plant species richness, vegetation cover and habitat type on the species composition of isopod and millipede assemblages was tested by redundancy analysis (RDA). The data for both taxa were used in the same analysis. A Hellinger transformation was performed for the species matrix allowing the use of ordination methods such as the Euclidean-based RDA, with community composition data containing many zeros (Legendre and Gallagher, 2001).

All analyses were performed using the mvabund (Wang et al., 2012), vegan (Oksanen et al., 2015) and BiodiversityR (Kindt and Coe, 2005) packages of R 3.0.1 (R Development Core Team, 2013).

\section{Results}

In total 2362 individuals of 8 macrodecomposer species were identified from samples collected by the pitfall traps, including 417 individuals of three isopod species (Armadillidium vulgare, Latreille, 1804; Trachelipus rathkii, Brandt, 1833; Trachelipus nodulosus, C. Koch, 1838) and 1945 individuals of five millipede species (Brachydesmus superus, Latzel, 1884; Brachyiulus bagnalli, Brölemann, 1924; Iulus terrestris, Linnaeus, 1758; Leptoiulus cibdellus, Chamberlin, 1921; Megaphyllum unilineatum, C. Koch, 1838). The most abundant species were L. cibdellus (Diplopoda) and A. vulgare (Isopoda: Oniscidea) representing $60 \%$ of all individuals. The total abundance of the studied macrodecomposers was highest in set-aside fields, with 261 individuals of isopods and 1250 individuals of millipedes. The lowest abundances were recorded within wheat fields (61 individuals of isopods and 611 of millipedes, respectively). In semi-natural grasslands, 95 isopod and 84 millipede specimens were collected. We found the lowest average number of isopods per field in 1-year-old set-aside (Sa1: 3.6/field) and winter wheat fields (W: 4/field). The average number of individuals increased with the age of set-aside areas: 3year-old set-aside had the highest average number of isopods per field (Sa3: 43.6/field). Millipedes showed the highest mean values in 2-year-old set-aside fields (Sa2: 139.5/field). Grasslands proved to be the poorest habitats regarding average numbers of millipedes (G: $14 /$ field).

Results of the Wilcoxon-signed rank tests showed that species richness $(p=0.045)$ and abundance $(p=0.008)$ of isopods was significantly higher in set-aside than in wheat fields. No significant effects were observed in the case of millipedes. At species level we found that almost all species occurred in higher number in setaside fields within the field pairs. In the case of L. cibdellus there was no significant difference between wheat and set-aside fields. $B$. bagnalli was present more frequently in wheat fields within the field pairs (Table 1 ).

The rarefaction curves showed a difference among habitat types for macrodecomposers: set-aside fields and grasslands had higher species richness than wheat fields. The rarefaction curve for grasslands did not reach an asymptote (Fig. 1). 
Table 1

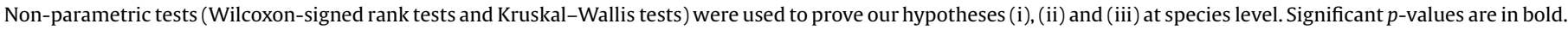
(Sa: set-aside fields, W: wheat fields).

\begin{tabular}{|c|c|c|c|c|c|c|}
\hline & \multirow{2}{*}{\multicolumn{2}{|c|}{$\begin{array}{l}\text { Wilcoxon signed rank test } \\
\text { Set-aside } \sim \text { wheat fields (i) }\end{array}$}} & \multicolumn{4}{|c|}{ Kruskal-Wallis rank sum test } \\
\hline & & & \multicolumn{2}{|c|}{$\overline{\text { Effectiveness of set-aside fields (ii) }}$} & \multicolumn{2}{|c|}{ Age effect on adjacent wheat fields (iii) } \\
\hline & Habitat & $p$ & Chi-square & $p$ & Chi-square & $p$ \\
\hline \multicolumn{7}{|l|}{ Isopods } \\
\hline Armadillidium vulgare & $\mathrm{Sa}>\mathrm{W}$ & 0.021 & 11.66 & 0.003 & 13.20 & 0.001 \\
\hline Trachelipus rathkii & $\mathrm{Sa}>\mathrm{W}$ & 0.001 & 4.99 & 0.083 & 4.48 & 0.106 \\
\hline \multicolumn{7}{|l|}{ Millipedes } \\
\hline Brachyiulus bagnalli & $\mathrm{Sa}<\mathrm{W}$ & 0.006 & 14.86 & $<\mathbf{0 . 0 0 1}$ & 17.40 & $<\mathbf{0 . 0 0 1}$ \\
\hline Iulus terrestris & $\mathrm{Sa}>\mathrm{W}$ & 0.013 & 8.20 & 0.017 & 5.13 & 0.077 \\
\hline Leptoiulus cibdellus & $\mathrm{Sa}>\mathrm{W}$ & 0.336 & 5.23 & 0.073 & 0.10 & 0.951 \\
\hline Megaphyllum unilineatum & $\mathrm{Sa}>\mathrm{W}$ & 0.006 & 14.00 & $<\mathbf{0 . 0 0 1}$ & 4.92 & 0.085 \\
\hline
\end{tabular}

The species richness and abundance of both decomposer taxa showed a similar increasing trend with the age of set-aside fields. In 3-year-old set-aside fields isopods showed similar or higher values than in grasslands. In the case of millipedes there were significantly higher species richness and abundance in 2- and 3-year-old set-aside fields than in grasslands (Fig. 2).

At group level, the effectiveness of management increased significantly with the age of set-aside fields with regard to species richness and abundance of isopods. In the case of millipedes we found a similar trend with significant difference (Fig. 3). Abundance of millipedes was highest in the case of 2-year-old set-aside fields. We found significantly higher effectiveness of set-aside management in the case of almost all species in 3-year-old set-aside fields than in younger ones. In the case of $L$. cibdellus and T. rathkii there was no significant difference. Moreover for $B$. bagnalli this effectiveness decreased with the age of set-aside fields (Table 1 ).

Species richness and abundance of isopods was significantly different between wheat fields adjacent to different aged set-aside fields. Wheat fields adjacent to 2- and 3-year-old set-aside fields had higher millipede abundance and species richness than those next to 1-year-old ones (Fig. 4). Species level analyses proved a significantly higher individual number of $B$. bagnalli in wheat fields adjacent to 2- and 3-year-old set-aside than in wheat fields besides 1 -year-old ones. Armadillidium vulgare occurred more frequently in wheat fields adjacent to 1-year-old set-aside than older ones (Table 1).

According to GLMM, the habitat type significantly affected all isopod and millipede species. Plant species richness had a significant effect on each species (except for $B$. bagnalli and $I$. terrestris). Wheat fields were the poorest in terms of plant species richness, while the 3-year-old set-aside fields were the richest. In the case of B. bagnalli, I. terrestris and L. cibdellus there was a significant effect of vegetation cover. The proportion of bare ground was lowest in wheat fields. Vegetation cover decreased with the age of set-aside fields. Plant species richness-vegetation cover interaction significantly affected the presence of $B$. bagnalli while having a marginally significant effect on $L$. cibdellus (Table 2).

Plant species richness had a significant effect on the composition of macrodecomposer communities $(F=4.27, p=0.042)$. Habitat type showed a similar trend $(F=2.43, p=0.071)$ but vegetation cover had no effect on the species composition of macrodecomposers. The RDA model explained $31 \%$ of the variation in the species data (eigenvalues: Axis $1=27.57 \%$, Axis $2=3.27 \%$, Axis $3=0.007 \%$ ) (Fig. 5).

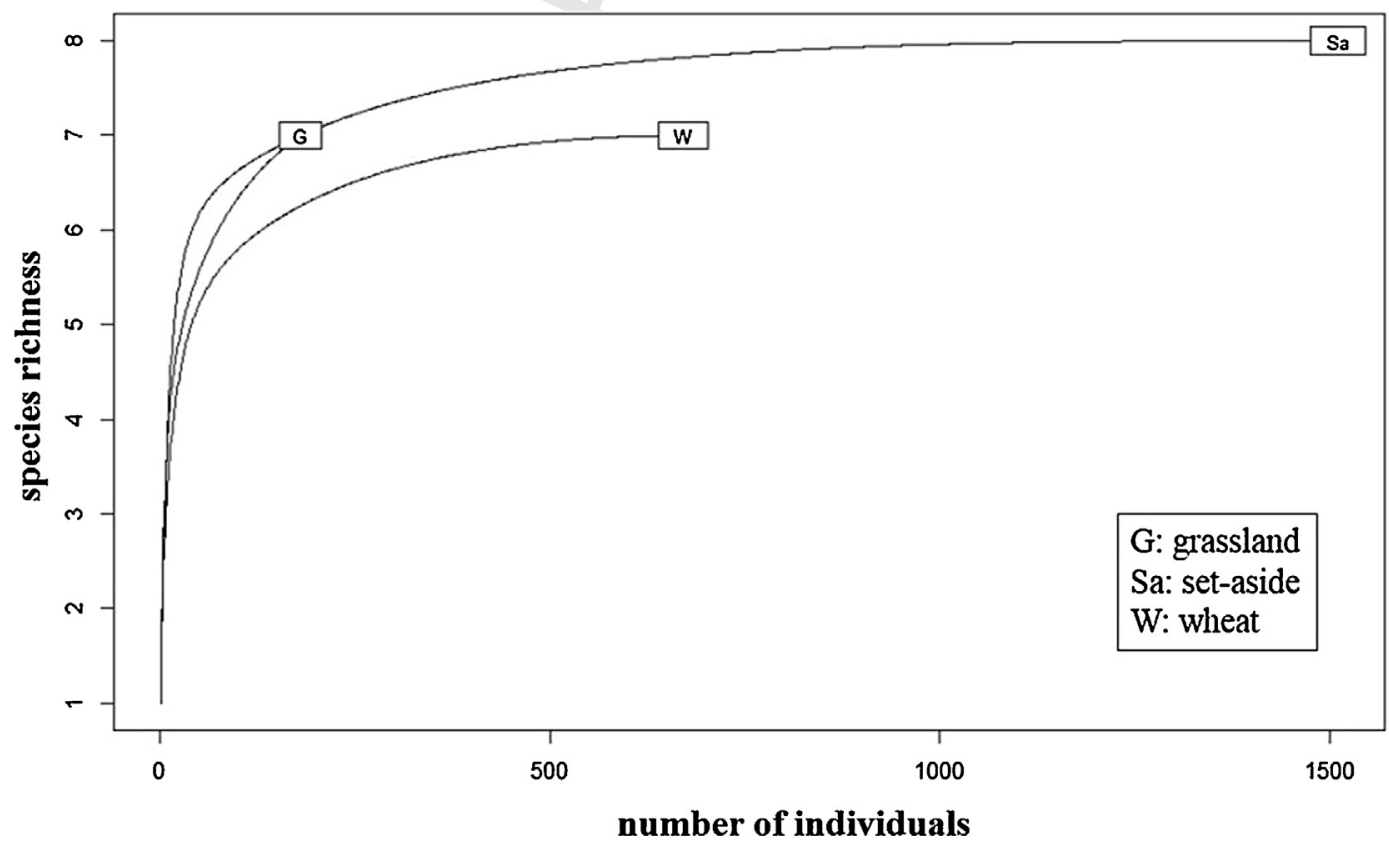

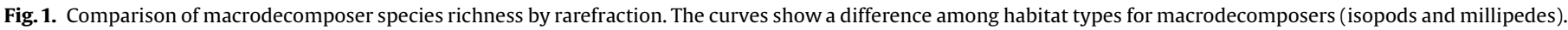


A

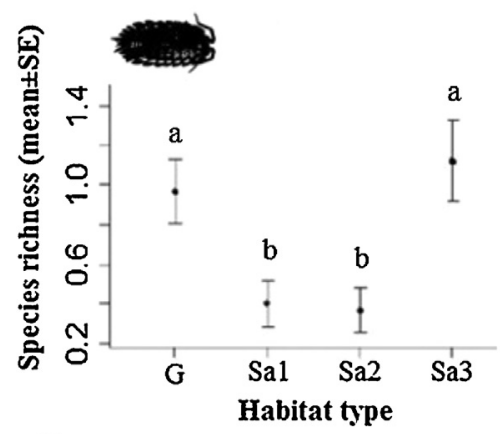

C

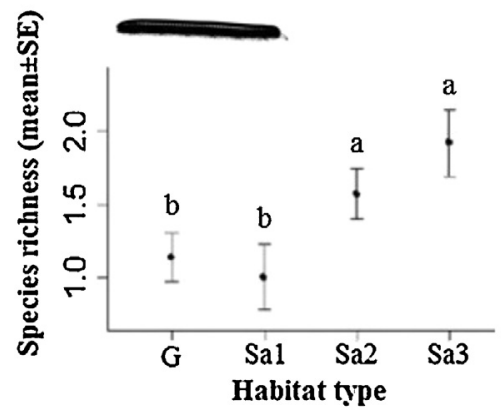

B

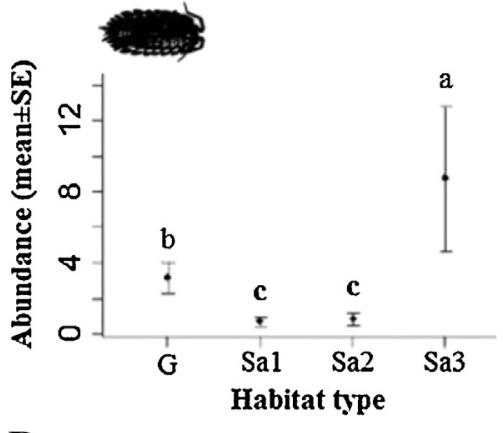

D

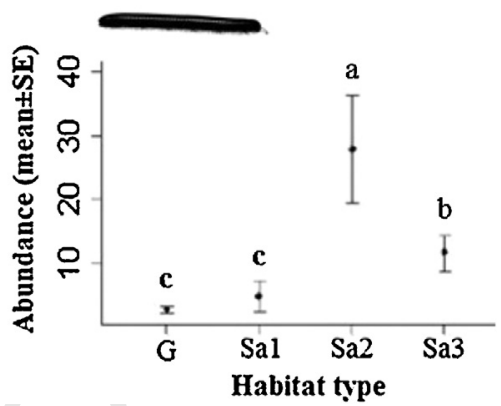

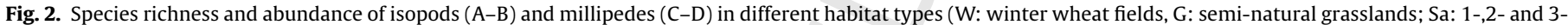
year-old set-aside fields). Please note the different scaling for the $Y$ axes. Letters indicate significant differences among the means (Dunn's test, $p<0.05$ ).

\section{Discussion}

The species richness of isopods and millipedes reflected the species numbers and species composition characteristic of the region. In most cases 1-3 isopod and 1-2 millipede species were found in the grassland-agricultural landscape continuum of the lowland area in Hungary (Korsós and Hornung, unpublished results). The rarefaction curves showed higher species richness of macrodecomposers in set-aside fields than in wheat fields. However in the case of grasslands they did not reach an asymptote which could mean a higher potential for species richness in these habitats.

Our results showed higher species richness and abundance of terrestrial isopods in set-aside than in wheat fields. The absence of
A

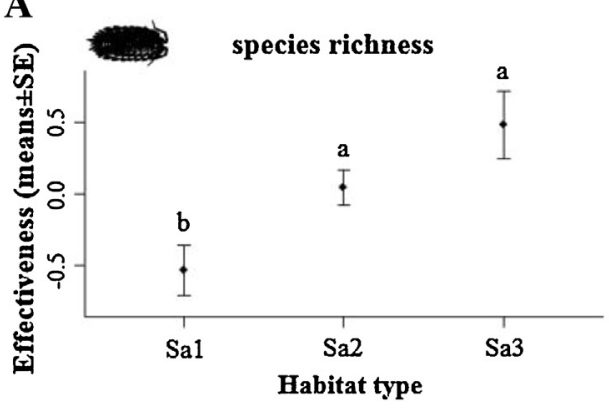

C

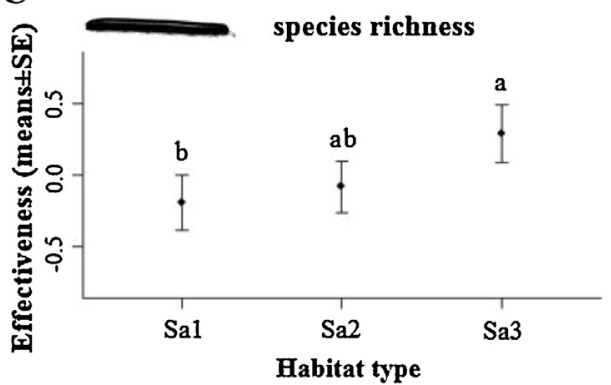

B

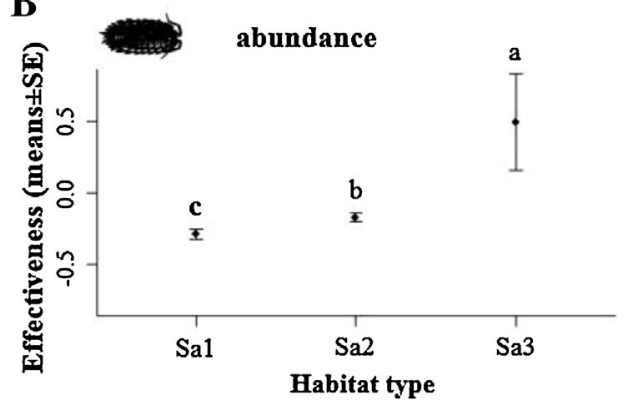

$\mathbf{D}$

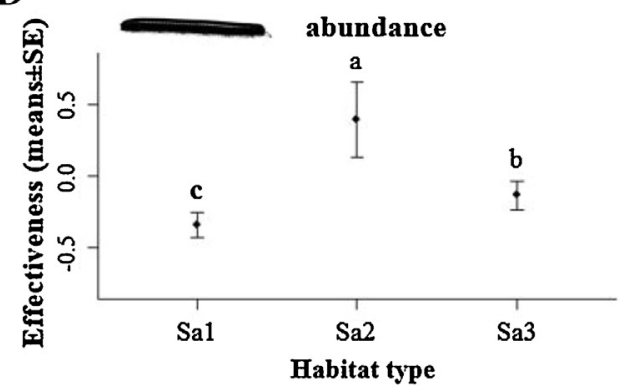

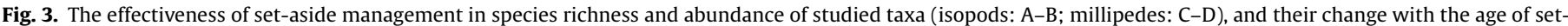

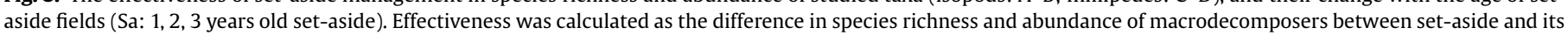
winter wheat field pair. $Y$ axes show standardised values. Letters indicate significant differences among the means (Dunn's test, $p<0.05$ ). 
A

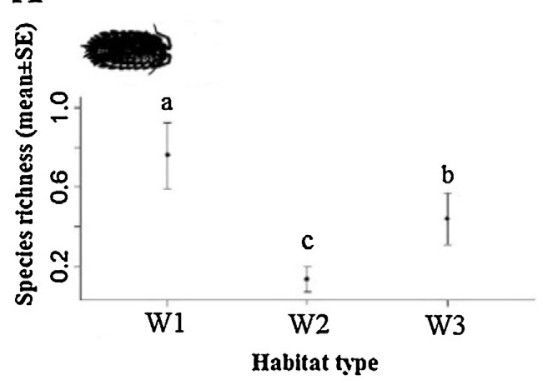

C

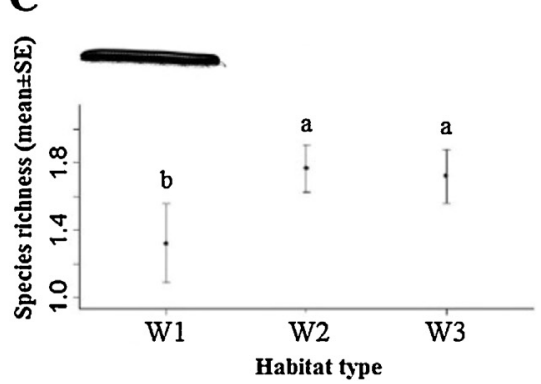

B

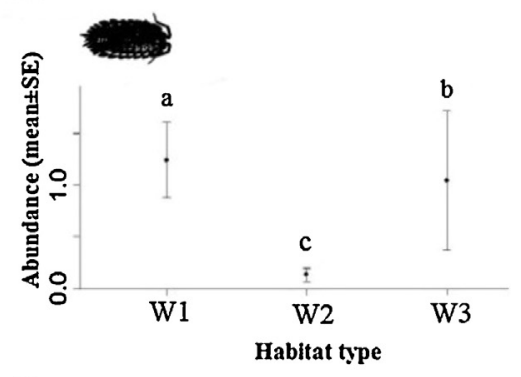

$\mathbf{D}$

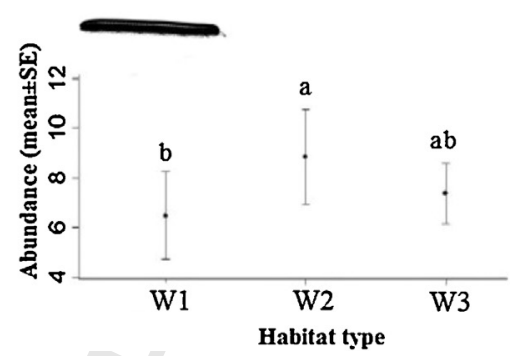

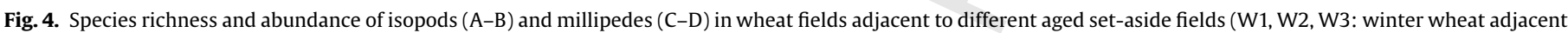
to 1-, 2- and 3-year-old set-aside). Note that $Y$ axes are scaled differently. Letters indicate significant differences among the means (Dunn's test, $p<0.05$ ).

agricultural practices (use of agrochemicals, tillage disturbance etc.) leads to successional changes toward semi-natural habitats harbouring more favourable conditions for macro-arthropods (Smith et al., 2008). This corresponds with the findings of Paoletti and Hassall (1999) who found a decreased isopod diversity and abundance in intensively managed agricultural fields. They found that the application of herbicides reduced the availability of food resources for isopods by the elimination of dicotyledonous plants as 'good quality food' (Rushton and Hassall, 1987). Both groups studied feed on dead plant material and are influenced by litter quality (C:N ratio, lignin content) (Seeber et al., 2009; Gerlach et al., 2014). The abundance of millipedes is also negatively affected by intense agricultural management, depending on landscape composition (Diekötter et al., 2010). We did not investigate the effect of landscape composition in the present study, but we did not find a significant effect of agricultural management compared to setaside management on millipede numbers. Different habitat preference of isopods and millipedes can be explained by physiological attributes: millipedes are less sensitive to microclimatic effects and are more drought resistant (Morón-Ríos et al., 2010) than isopods. Soil temperature and moisture content are the main abiotic background factors influencing the presence and abundance of the animals in question, especially that of the terrestrial isopods. Their exoskeleton is permeable to water, therefore desiccation threat restricts their occurrence to habitats with higher humidity and suitable shelter sites (Hopkin and Read, 1992; Warburg et al., 1984; Warburg, 1987, 1993).

We assume that more favourable microclimatic conditions might be available in set-aside fields largely due to the higher plant diversity and more complex vegetation structure. In addition to food resources, they provide favourable habitats (shelter sites) for these humidity dependent macrodecomposers, especially for isopods. This corresponds with a previous study of Birkhofer et al. (2011) where they found that the feeding activity of soil fauna was positively affected by legume and grass species richness. Previous studies related to the age effect of set-aside are in accordance with the present results (Corbet, 1995; KovácsHostyánszki et al., 2011). However millipedes were most abundant in the 2-year-old set-aside fields and also corresponds with certain studies (Gathmann et al., 1994; Steffan-Dewenter and Tscharntke, 1997, 2001). Nevertheless it is important to note that this phenomenon was mostly due to the mass occurrence of $L$. cibdellus.

Our study demonstrates the beneficial impact of older set-aside fields on the adjacent wheat fields only in the case of B. bagnalli. In contrast to the other macrodecomposer species present, this occurred more frequently in wheat than in set-aside fields.

Table 2

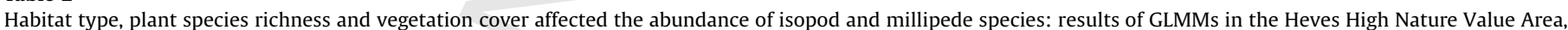
Hungary. Significant $p$-values are in bold. Number in italics is marginally significant.

\begin{tabular}{|c|c|c|c|c|c|c|c|c|}
\hline & \multicolumn{2}{|c|}{ Habitat } & \multicolumn{2}{|c|}{ Plant species richness } & \multicolumn{2}{|c|}{ Vegetation cover } & \multicolumn{2}{|c|}{ Plant species richness: Vegetation cover } \\
\hline & Dev & $p$ & Dev & $p$ & Dev & $p$ & Dev & $p$ \\
\hline \multicolumn{9}{|l|}{ Isopods } \\
\hline Armadillidium vulgare & 30.97 & 0.001 & 10.85 & 0.014 & 1.91 & 0.308 & 0.04 & 0.859 \\
\hline Trachelipus rathkii & 27.60 & 0.001 & 14.27 & 0.006 & 0.00 & 0.996 & 0.76 & 0.61 \\
\hline \multicolumn{9}{|l|}{ Millipedes } \\
\hline Brachyiulus bagnalli & 32.80 & 0.001 & 1.62 & 0.492 & 6.44 & 0.045 & 8.78 & 0.013 \\
\hline Iulus terrestris & 18.47 & 0.003 & 1.52 & 0.492 & 28.56 & 0.001 & 0.14 & 0.801 \\
\hline Leptoiulus cibdellus & 40.74 & 0.001 & 8.63 & 0.024 & 7.12 & 0.041 & 5.43 & 0.058 \\
\hline Megaphyllum unilineatum & 35.46 & 0.001 & 17.86 & 0.001 & 0.18 & 0.69 & 0.36 & 0.801 \\
\hline
\end{tabular}




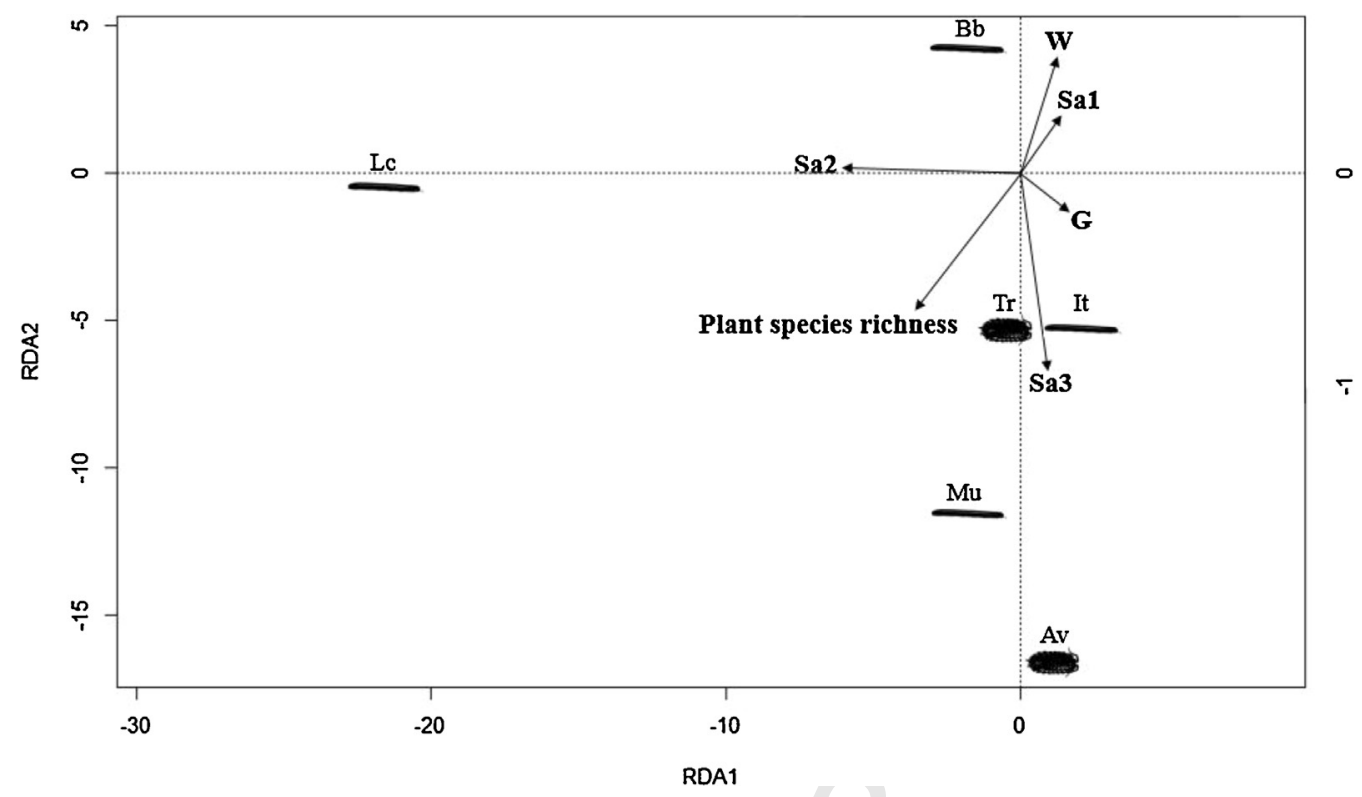

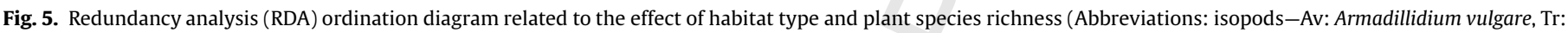

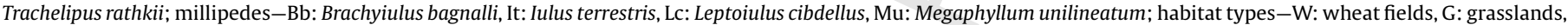
Sa1, Sa2, Sa3: 1, 2 and 3-year-old set-aside).

Increased abundance in connection with the age of set-aside management might be attributed to the "spillover effect", although it was not pronounced due to the short distance migration ability of isopods and millipedes (Hopkin and Read, 1992; Warburg, 1993).

The present study highlights the common factors regulating the distribution of isopods and millipedes through their similar habitat preferences. However, in some cases their reaction to changes in plant diversity, vegetation cover and habitat type was different. This phenomenon could be explained by several interacting effects and their variable, taxon dependent sensibility/tolerance to environmental background factors. Species within the same major taxonomic group showed contrasting preferences for habitat types. For instance, L. cibdellus mostly occurred in set-aside fields, whereas B. bagnalli was observed most frequently in wheat fields. This corresponds to the results of previous work (Schubart, 1934; Blower, 1985) dealing with species' distribution and habitat preference: L. cibdellusfavours semi-natural habitats so it can be an indicator of habitat quality as well (Paoletti et al., 2007). Brachyiulus bagnalli has a wide habitat preference, occurring in xerothermic grasslands, floodplain forests and human influenced habitats like arable lands, too. The isopod species, A. vulgare is a habitat generalist and appears in all kinds of habitat in Hungary. T. rathkii also has a broad tolerance to a wide range of habitat types, from semi-natural to disturbed ones (Hornung et al., 2008; Vilisics et al., 2007).

\section{Conclusions}

Our study highlights the importance of set-aside management system with regard to surface dwelling invertebrates. The results presented support the effectiveness of set-aside management to ensure higher species richness in accordance with the results of Van Buskirk and Willi (2004). Set-aside fields function as seminatural habitats providing favourable conditions for macrodecomposers particularly after an initial establishment period of two years, supporting the regeneration of soil biological resources. Setaside fields that are not part of a crop rotation for more than 2 years could be a valuable option for establishing ecological focus areas under the CAP (Common Agricultural Policy) 2013 reform in the
$\mathrm{EU}$, as these fields may simultaneously conserve elements of above- and belowground diversity.

However further research is required to look for the optimum management regimes for soil related organisms supporting the most abundant and diverse arthropod populations, particularly in relation to the establishment methods of set-aside or other seminatural habitat types in agricultural landscapes.

\section{Acknowledgements}

The authors thank the Bükk National Park Directorate and the landowners for permission to work on their fields. Our particular thanks go to Dorottya Angyal and Dr. Zoltán Korsós (Hungarian Natural History Museum) for their help in millipede identification. We are grateful to Dr. Zsolt Lang (Szent István University, Faculty of Veterinary Science) for statistical advices. Grateful thanks to Dr. Péter Sólymos (University of Alberta, Canada) and Dr. Helen Read (Burnham Beeches, London, UK) for their useful comments and friendly help in English usage. The three anonymous reviewers gave very helpful criticism and pinpointed essential problems giving useful advice to improve our previous manuscript. A.K.-H. was a Bolyai Fellow and a HAS Postdoc Fellow during the preparation of the paper. This research was financially supported by the LIBERATION EU FP7 project (FP7 KBBE 311781).

\section{Appendix A. Supplementary data}

Supplementary data associated with this article can be found, in the online version, at http://dx.doi.org/10.1016/j. apsoil.2015.11.003.

\section{References}

Altieri, M.A., 1994. Biodiversity and Pest Management in Agroecosystems. Haworth Press, New York.

Altieri, M.A., 1999. The ecological role of biodiversity in agroecosystems. Agric. Ecosyst. Environ. 74, 19-31. doi:http://dx.doi.org/10.1016/S0167-8809(99) 00028-6.

Ángyán, J., Tardy, J., Vajnáné Madarassy, A. (Eds.), 2003. Védett és érzékeny természeti területek mezőgazdálkodásának alapjai (Agriculture of Protected and Environmentally Sensitive Areas). Mezőgazda Kiadó, Budapest. 
Barrios, E., 2007. Soil biota, ecosystem services and land productivity. Ecol. Econ. 64 (2), 269-285. doi:http://dx.doi.org/10.1016/j.ecolecon.2007.03.004.

Birkhofer, K., Diekötter, T., Boch, S., Fischer, M., Müller, J., Socher, S., Wolters, V., 2011. Soil fauna feeding activity in temperate grassland soils increases with legume and grass species richness. Soil Biol. Biochem. 43, 2200-2207. doi:http://dx.doi. org/10.1016/j.soilbio.2011.07.008.

Blitzer, E.J., Dormann, C.F., Holzschuh, A., Klein, A.M., Rand, T.A., Tscharntke, T., 2012. Spillover of functionally important organisms between managed and natural habitats. Agric. Ecosyst. Environ. 146, 34-43. doi:http://dx.doi.org/10.1016/j. agee.2011.09.005.

Blower, J.G., 1985. Millipedes-Keys and Notes for the Identification of the Species. The Bath Press, Avon, UK.

Brussaard, L., de Ruiter, P.C., Brown, G.G., 2007. Soil biodiversity for agricultural sustainability. Agric. Ecosyst. Environ. 121, 233-244. doi:http://dx.doi.org/ 10.1016/j.agee.2006.12.013.

Bükk National Park, 2015. Hevesi Füves Puszták Tájvédelmi Körzet (Heves Steppe Grasslands Landscape Protection Area). URL: http://bnpi.hu/oldal/hevesi-fuvespusztak-tk-55html (verified on the 06.10.15.).

Cardinale, B.J., Duffy, J.E., Gonzalez, A., Hooper, D.U., Perrings, C., Venail, P., Narwani, A., Mace, G.M., Tilman, D., Wardle, D.A., Kinzig, A.P., Daily, G.C., Loreau, M., Grace, J.B., Larigauderie, A., Srivastava, D.S., Naeem, S., 2012. Biodiversity loss and its impact on humanity. Nature 486, 59-67. doi:http://dx.doi.org/10.1038/ nature 11148.

Corbet, S.A., 1995. Insects, plants and succession: advantages of long-term set-aside, Agric. Ecosyst. Environ. 53, 201-217. doi:http://dx.doi.org/10.1016/0167-8809 (94) 00581-X.

Critchley, C.N.R., Allen, D.S., Fowbert, J.A., Mole, A.C., Gundrey, A.L., 2004. Habitat establishment on arable land: assessment of an agri-enviroment scheme in England, UK. Biol. Conserv. 119, 429-442. doi:http://dx.doi.org/10.1016/j. biocon.2004.01.004.

Culliney, T.W., 2013. Role of Arthropods in maintaining soil fertility. Agriculture 3 , 629-659. doi:http://dx.doi.org/10.3390/agriculture3040629.

Dauber, J., Purtauf, T., Allspach, A., Frisch, J., Voigtländer, K., Wolters, V., 2005. Local vs. landscape controls on diversity: a test using surface-dwelling soil macroinvertebrates of differing mobility. Global Ecol. Biogeogr. 14, 213-221. doi: http://dx.doi.org/10.1111/j.1466-822X.:1;2005.00150.x.

Diekötter, T., Wamser, S., Wolters, V., Birkhofer, K., 2010. Landscape and management effects on structure and function of soil arthropod communities in winter wheat. Agric. Ecosyst. Environ. 137 (1-2), 108-112. doi:http://dx.doi.org/ 10.1016/j.agee.2010.01.008.

Dominati, E., Patterson, M., Mackay, A., 2010. A framework for classifying and quantifying the natural capital and ecosystem services of soils. Ecol. Econ. 69, 1858-1868. doi:http://dx.doi.org/10.1016/j.ecolecon.2010.05.002

Dudgeon, D., Ma, H.H.T., Lam, P.K.S., 1990. Differential palatability of leaf litter to four sympatric isopods in a Hong Kong forest. Oecologia 84, 398-403. doi: http://dx.doi.org/10.1111/j.1469-7998.1991.tb06030.x.

Gathmann, A., Greiler, H.J., Tscharntke, T., 1994. Trap-nesting bees and wasps colonizing set-aside fields: succession and body size, management by cutting and sowing. Oecologia 98, 8-14. doi:http://dx.doi.org/10.1007/bf00326084.

Gerlach, A., Russell, D.J., Jaeschke, B., Römbke, J., 2014. Feeding preferences of native terrestrial isopod species (Oniscoidea, Isopoda) for native and introduced leaf litter. Appl. Soil Ecol. 83, 95-100. doi:http://dx.doi.org/10.1016/j. apsoil.2014.02.006

Giller, K.E., Beare, M.H., Lavelle, P., Izac, A.M.N., Swift, M.J., 1997. Agricultural intensification, soil biodiversity and agroecosystem function. Appl. Soil Ecol. 6 , 3-16. doi:http://dx.doi.org/10.1016/s0929-1393(96) 00149-7.

Gruner, H., 1966. Die Tierwelt Deutschlands. 53. Teil. Krebstiere oder Crustacea. V. Isopoda, 2. Lieferung, Jena.

Hassall, M., 1966. Spatial variation in favourability of a grass heath as a habitat for woodlice (Isopoda: Oniscidea). Pedobiologia 40, 514-528.

Hassall, M., Turner, J.G., Rands, M.R.W., 1987. Effects of terrestrial isopods on the decomposition of woodland leaf litter. Oecologia 72, 597-604. doi:http://dx.doi. org/10.1007/bf00378988.

Hättenschwiler, S., Bretscher, D., 2001. Isopod effects on decomposition of litter produced under elevated $\mathrm{CO} 2, \mathrm{~N}$ deposition and different soil types. Global Change Biol. 7, 565-579. doi:http://dx.doi.org/10.1046/j. 13652486.2001.00402.x.

Hättenschwiler, S., Tiunov, A.V., Scheu, S., 2005. Biodiversity and litter decomposition in terrestrial ecosystems. Annu. Rev. Ecol. Evol. System. 36, 191-218. doi:http://dx.doi.org/10.1146/annurev.ecolsys.36.112904.151932.

Hopkin, S.P., Read, H.J., 1992. The Biology of Millipedes. Oxford University Press, Oxford.

Hornung, E., Vilisics, F., Sólymos, P., 2008. Low $\alpha$ - and high $\beta$-diversity in terrestrial isopod assemblages in the Transdanubian region of Hungary. In: Zimmer, M. Charfi-Cheikhrouha, F., Taiti, S. (Eds.), Proceedings of the International Symposium of Terrestrial Isopod ISTIB -07. Shaker Verlag, Aachen, Germany 111 ISBN 978-3-8322-6418-5.

Kindt, R., Coe, R., 2005. Tree diversity analysis. A manual and software for common statistical methods for ecological and biodiversity studies. World Agroforestry Centre (ICRAF), Nairobi ISBN 92-9059-179-X.

Korsós, Z. 2015. Magyarország ikerszelvényesei. Illusztrációtáblák és adatlapok a fajok meghatározásához (Diplopods of Hungary. Illustrations and data sheets to species identification.)-unpublished manuscript. Hungarian Natural History Museum, Budapest.

Kovács-Hostyánszki, Á., Kőrösi, Á., Orci, K.M., Batáry, P., Báldi, Á., 2011. Set-aside promotes insect and plant diversity in a Central European country. Agric.
Ecosyst. Environ. 141, 296-301. doi:http://dx.doi.org/10.1016/j. agee.2011.03.004

Kovács-Hostyánszki, A., Báldi, A., 2012. Set-aside fields in agri-environment schemes can replace the market-driven abolishment of fallows. Biol. Conserv. 152, 196-203. doi:http://dx.doi.org/10.1016/j.biocon.2012.03.039.

Kuussaari, M., Hyvönen, T., Härmä, O., 2011. Pollinator insects benefit from rotational fallows. Agric. Ecosyst. Environ. 143, 28-36. doi:http://dx.doi.org/ 10.1016/j.agee.2011.03.006

Laossi, K.R., Barot, S., Carvalho, D., Desjardins, T., Lavelle, P., Martins, M., Mitja, D. Rendeiro, A.C., Rousseau, G., Sarrazin, M., Velasquez, E., Grimaldi, M., 2008. Effects of plant diversity on plant biomass production and soil macrofauna in Amazonian pastures. Pedobiologia 51, 397-407. doi:http://dx.doi.org/10.1016/j. pedobi.2007.11.001.

Lavelle, P., Spain, A.V., 2001. Soil Ecology. Kluwer Scientific, Amsterdam.

Legendre, P., Gallagher, E.D., 2001. Ecologically meaningful transformations for ordination of species data. Oecologia 129, 271-280. doi:http://dx.doi.org/ $10.1007 /$ s004420100716.

Marshall, E.J.P., Moonen, A.C., 2002. Field margins in northern Europe: their functions and interactions with agriculture. Agric. Ecosyst. Environ. 89, 5-21. doi:http://dx.doi.org/10.1016/s0167-8809(01) 00315-2.

Melbourne, B.A., 1999. Bias in the effect of habitat structure on pitfall traps: an experimental evaluation. Aust. J. Ecol. 24, 228-239. doi:http://dx.doi.org/ 10.1046/j.1442-9993.1999.00967.x.

Morón-Ríos, Á., Rodríguez, M.Á., Pérez-Camacho, L., Rebollo, S., 2010. Effects of seasonal grazing and precipitation regime on the soil macroinvertebrates of a Mediterranean old-field. Eur. J. Soil Biol. 46, 91-96. doi:http://dx.doi.org/ 10.1016/j.ejsobi.2009.12.008.

Obrist, M.K., Duelli, P., 1996. Trapping efficiency of funnel-and cup-traps for epigeal arthropods. Mitt. Schw. Ent. Ges 69, 361-369.

Oksanen, J., Blanchet, F. G., Kindt, R., Legendre, P., Minchin, P. R., O'Hara, R. B., Simpson, G. L., Sólymos, P., Stevens, M. H. H., Wagner, H., 2015. Vegan: Community Ecology Package. URL: http://CRAN.R-project.org/package=vegan.

Paoletti, M.G., 1995. Hedgerow evolution and function in Italian landscapes and EC Policies. In: Joerg, E. (Ed.), Field Margin-Strip Programmes. Landeranstalt fur Pflanzenbau und Pflanzenschutz, Mainz, Germany, pp. 112-116.

Paoletti, M.G., Boscolo, P., Sommaggio, D., Predators-, parasitoids and, 1997. beneficial insects in fields surrounded by hedgerows in North Eastern Italy. Entomo. Res. Org. Agric. Biol. Agric. Hortic. 15 (1-4), 311-323.

Paoletti, M.G., Hassall, M. 1999. Woodlice (Isopoda: Oniscidea): their potential for assessing sustainability and use as bioindicators. Agric. Ecosyst. Environ. 74 (1-3), 157-166. doi:http://dx.doi.org/10.1016/s0167-8809(99)00035-3.

Paoletti, M.G., Osler, G.H.R., Kinnear, A., Black, D.G., Thomson, L.J., Tsitsilas, A., Sharley, D., Judd, S., Neville, P., D'Inca, A., 2007. Detritivores as indicators of landscape stress and soil degradation. Aust. J. Exp. Agr. 47, 412-423. doi:http:// dx.doi.org/10.1071/ea05297.

Pollard, E., 1968. Hedges. II. The effect of removal of the bottom flora of a hawthorn hedgerow on the fauna of the hawthorn. J. Appl. Ecol. 5, 109-123.

R Development Core Team, 2013. R: A Language and Environment for Statistical Computing. R Foundation For Statistical Computing, Vienna, Austria. http:// www.r-project.org.

Rowe, R.L., Street, N.R., Taylor, G., 2009. Identifying potential environmental impacts of large-scale deployment of dedicated bioenergy crops in the UK. Renew. Sust. Energ. Rev. 13, 260-279. doi:http://dx.doi.org/10.1016/j.rser.2007.07.008.

Rushton, S.P., Hassall, M., 1987. Effects of food quality on isopod population dynamics. Funct. Ecol. 1 (4), 359-367. doi:http://dx.doi.org/10.2307/2389792.

Scheu, S., 2002. The soil food web: structure and perspectives. Eur. J. Soil Biol. 38 11-20. doi:http://dx.doi.org/10.1016/s1164-5563(01) 01117-7.

Schubart, O., 1934. Tausendfüssler oder Myriapoda I: Diplopoda. In: Dahl, F. (Ed.), Die Tierwelt Deutschlands und der angränzenden Meeresteile, Teil 28. Gustav Fischer Verlag, Jena.

Seeber, Langel, J., Meyer, R., Traugott, E., M, 2009. Dwarf shrub litter as a food source for macro-decomposers in alpine pastureland. Appl. Soil Ecol. 41 (2), 178-184. doi:http://dx.doi.org/10.1016/j.apsoil.2008.10.006.

Sileshi, G., Mafongoya, P.L., Chintu, R., Akinnifesi, F.K., 2008. Mixed-species legume fallows affect faunal abundance and richness and $\mathrm{N}$ cycling compared to single species in maize-fallows rotations. Soil Biol. Biochem. 40, 3065-3075. doi: http://dx.doi.org/10.1016/j.soilbio.2008.09.007.

Slade, E.M., Riutta, T., 2012. Interacting effects of leaf litter species and macrofauna on decomposition in different litter environments. Basic Appl. Ecol. 13, 423-431. doi:http://dx.doi.org/10.1016/j.baae.2012.06.008.

Smith, J., Potts, S., Eggleton, P., 2008. The value of sown grass margins for enhancing soil macrofaunal biodiversity in arable systems. Agr. Ecosyst. Environ. 127, 119-125. doi:http://dx.doi.org/10.1016/j.agee.2008.03.008.

Smith, J., Potts, S.G., Woodcock, B.E., Eggleton, P., 2009. The impact of two arable field margin management schemes on litter decomposition. Appl. Soil Ecol. 41, 90-97. doi:http://dx.doi.org/10.1016/j.apsoil.2008.09.003.

Smith, V.C., Bradford, M.A., 2003. Litter quality impacts on grassland litter decomposition are differently dependent on soil fauna across time. Appl. Soil Ecol. 24, 197-203. doi:http://dx.doi.org/10.1016/s0929-1393(03) 00094-5.

Sotherton, N.W., 1998. Land use changes and the decline of farmland wildlife: an appraisal of the set-aside approach. Biol. Conserv. 83, 259-268. doi:http://dx. doi.org/10.1016/s0006-3207(97) 00082-7.

Souty-Grosset, C., Badenhausser, I., Reynolds, J.D., Morel, A., 2005. Investigations on the potential of woodlice as bioindicators of grassland habitat quality. Eur. J. Soil Biol. 41, 109-116. doi:http://dx.doi.org/10.1016/j.ejsobi.2005.09.009. 
Steffan-Dewenter, I., Tscharntke, T., 1997. Early succession of butterfly and plant communities on set-aside fields. Oecologia 109, 294-302. doi:http://dx.doi.org/ $10.1007 / 5004420050087$.

Steffan-Dewenter, I., Tscharntke, T., 2001. Succession of bee communities on fallows. Ecography 24, 83-93. doi:http://dx.doi.org/10.1034/j.16000587.2001.240110.x.

Stork, N.E., Eggleton, P., 1992. Invertebrates as determinants and indicators of soil quality. Am. J. Altern. Agric. 7 (1-2), 38-47. doi:http://dx.doi.org/10.1017/ S00889189300004446.

Stoate, C., Báldi, A., Beja, P., Boatman, N.D., Herzon, I., van Doorn, A., de Snoo, G.R., Rakosy, L., Ramwell, C., 2009. Ecological impacts of early 21st century agricultural change in Europe -review. J. Environ. Manage. 91, 22-46. doi:http:// dx.doi.org/10.1016/j.jenvman.2009.07.005.

Toivonen, M., Herzon, I., Helenius, J., 2013. Environmental fallows as a new policy tool to safeguard farmland biodiversity in Finland. Biol. Conserv. 159, 355-366. doi:http://dx.doi.org/10.1016/j.biocon.2012.11.016.

Tripathi, G., Deora, R., Singh, G., 2013. The influence of litter quality and microhabitat on litter decomposition and soil properties in a silvopasture system. Acta Oecol. 50, 40-50. doi:http://dx.doi.org/10.1016/j.actao.2013.01.013.

Tsiafouli, M.A., Thébault, E., Sgardelis, S.P., De Ruiter, P.C., Van der Putten, W.H., Birkhofer, K., Hemerik, L., De Vries, F.T., Bardgett, R.D., Brady, M.V., Bjornlund, L., Jørgensen, H.B., Christensen, S., D'Hertefeldt, T., Hotes, S., Hol, W.H.G., Frouz, J. Liiri, M., Mortimer, S.R., Setälä, H., Tzanopoulos, J., Uteseny, K., Pižl, V., Stary, J., Wolters, V., Hedlund, K., 2015. Intensive agriculture reduces soil biodiversity across Europe. Global Change Biol. 21 (2), 973-985. doi:http://dx.doi.org/ $10.1111 / g c b .12752$.

Vanbergen, A.J., Watt, A.D., Mitchell, R., Truscott, A.M., Palmer, S.C.F., Ivits, E., Eggleton, P., Jones, T.H., Sousa, J.P., 2007. Scale-specific correlations between habitat heterogeneity and soil fauna diversity along a landscape structure gradient. Oecologia 153, 713-725. doi:http://dx.doi.org/10.1007/s00442-0070766-3.

Van Buskirk, J., Willi, Y., 2004. Enhancement of farmland biodiversity within setaside land. Conserv. Biol. 18, 987-994. doi:http://dx.doi.org/10.1111/j.15231739.2004.00359.x.

Vilisics, F., Sólymos, P., Hornung, E., 2007. Study on habitat features and associated terrestrial isopod species. In: Tajovský, K., Schlaghamerský, J., Pižl, V. (Eds.), Contributions to Soil Zoology in Central Europe II, , pp. 195-199.

Wang, Y., Naumann, U., Wright, S., Warton, D.I., 2012. mvabund: an R package for model-based analysis of multivariate data. Methods Ecol. Evol. 3, 471-474. https://cran.r-project.org/web/packages/mvabund/index.html.

Warburg, M.R., Linsenmair, K.E., Bercovitz, K., 1984. The effect of climate on the distribution and abundance of isopods. Sym. Zool. Soc. Lond. 53, 339-367.

Warburg, M.R., 1987. Isopods and their terrestrial environment. Adv. Ecol Res. 17, 187-242. doi:http://dx.doi.org/10.1016/S0065-2504(08)60246-9.

Warburg, M.R., 1993. Evolutionary Biology of Land Isopods. Springer, New York.

Wissuwa, J., Salamon, J.A., Frank, T., 2012. Effects of habitat age and plant species on predatory mites (Acari, Mesostigmata) in grassy arable fallows in Eastern Austria. Soil Biol. Biochem. 50, 96-107. doi:http://dx.doi.org/10.1016/j. soilbio.2012.02.025.

Wissuwa, J., Salamon, J.A., Frank, T., 2013. Oribatida (Acari) in grassy arable fallows are more affected by soil properties than habitat age and plant species. Eur. J. Soil Biol. 59, 8-14. doi:http://dx.doi.org/10.1016/j.ejsobi.2013.08.002.

Yang, X., Yang, Z., Warren, M.W., Chen, J., 2012. Mechanical fragmentation enhances the contribution of Collembola to leaf litter decomposition. Eur. J. Soil Biol. 53 , 23-31. doi:http://dx.doi.org/10.1016/j.ejsobi.2012.07.006.

Zimmer, M., Brauckmann, H.-J., Broll, G., Topp, W., 2001. Correspondence analytical evaluation of factors that influence soil macro-arthropod distribution in abandoned grassland. Pedobiologia 44, 695-704. doi:http://dx.doi.org/10.1078/ 0031-4056-00086. 